\title{
A CAPES E A FEBRASGO
}

Para que serve a FEBRASGO?

A resposta está no estatuto de nossa Federação. Na prática ela serve para tornar o especialista em GO eficiente em seu labor clínico. Para cumprir esta finalidade a Federação, além da atuação das comissões especializadas e dos eventos que promove ou apóia, possui duas revistas: RBGO, dedicada à divulgação de trabalhos de pesquisa e Femina voltada para estudos de atualização, de observação clínica, servindo de arrimo inestimável na prática diária dos tocoginecologistas. Certamente ambas são úteis para o bom atendimento das clientes. Femina é uma das publicações mais exitosas em nossa literatura médica e, por mérito, há mais de 30 anos é a revista da especialidade mais lida no Brasil.

RBGO é periódico com maior conceito junto à Capes. O corpo editorial da revista analisa metodologicamente os artigos enviados e assim orienta os autores na exposição de seus estudos seguindo as normas técnicas estabelecidas.

Entendemos que RBGO e Femina deveriam ter valorização semelhante pois ambas possuem corpo editorial selecionado e estritas normas editoriais. A elaboração dos artigos, na quase totalidade, é feita por eminentes professores pressurosos na divulgação das verdades científicas.

A FEBRASGO esmera-se na orientação de todos os tocoginecologistas na prestação de serviços qualificados e éticos. Há décadas mantém, sempre mais revigorado, o concurso para obtenção do Título de Especialista em GO (TEGO). Os congressos da FEBRASGO abrem espaço para a divulgação dos trabalhos de pesquisa elaborados em todo Brasil. Eventos organizados pelas Federadas Estaduais levam aos clínicos de todo o país conhecimentos úteis para as atividades diárias e para incremento dos próprios estudos e observações. Não acreditamos na existência de qualquer outro evento ou organização nacional que possibilitem semelhante troca de informações e crescimento científico.

Para que serve a Capes?

A Capes avalia programas de Mestrado e Doutorado através das produções científicas de cada curso. Basicamente controla as linhas de pesquisa e projetos vinculados. A metodologia é o fundamento dos trabalhos derivados dos projetos de pesquisa desenvolvidos pelos alunos destes cursos de pós-graduação. Um dos parâmetros de avaliação é a publicação de trabalhos nas linhas de pesquisa coordenadas pelos professores. As revistas da FEBRASGO, ambas, deveriam ser reconhecidas como eminente veículo nacional (exorcizando-se a febre xenófila de somente valorizar o que é estrangeiro) para divulgação destes estudos e, evidentemente, possuir crédito semelhante junto à Capes.

FEBRASGO e Capes deveriam continuar a trabalhar separadamente ou seria saudável parceria produtiva? A FEBRASGO dedica-se à assistência fornecendo cabedal não despiciendo de conhecimentos científicos a todos os associados. A Capes incumbe-se da supervisão dos cursos de pós-graduação stricto sensu que forma Professores, Mestres e Doutores, e usa parâmetros de avaliação perpassando pela produção científica exarada (ou assim deveria sê-lo) nas revistas da FEBRASGO. A FEBRASGO abriga estes professores. Eles ajudam os sócios na atividade de assistência, mantendo-os sempre atualizados.

Certamente a valorização pela CAPES dos trabalhos publicados nas revistas da FEBRASGO serviriam de incentivo para maior e melhor produção de artigos pela comunidade científica nacional.

A Diretoria 